\title{
Update on the Genetic Basis of Drug Hypersensitivity Reactions
}

\author{
Jurado-Escobar $\mathrm{R}^{1 *}$, Perkins $\mathrm{JR}^{1 *}$, García-Martín $\mathrm{E}^{2}$, Isidoro-García $\mathrm{M}^{3,4,5}$, \\ Doña $\mathrm{I}^{6}$, Torres MJ' ${ }^{6}$ Cornejo-García JA ${ }^{1,6}$
}

\author{
*Both authors contributed equally to the manuscript. \\ ${ }^{1}$ Research Laboratory, IBIMA, Regional University Hospital of Malaga, UMA, Malaga, Spain \\ 2Department of Pharmacology, University of Extremadura, Caceres, Spain \\ ${ }^{3}$ Department of Clinical Biochemistry, Pharmacogenetics Unit, University Hospital of Salamanca, Salamanca, \\ Spain \\ ${ }^{4}$ Institute for Biomedical Research of Salamanca (IBSAL), Allergy Department, Salamanca, Spain \\ ${ }^{5}$ Department of Medicine, Faculty of Medicine, University of Salamanca, Salamanca, Spain \\ ${ }^{6}$ Allergy Unit, IBIMA, Regional University Hospital of Malaga, UMA, Malaga, Spain
}

J Investig Allergol Clin Immunol 2017; Vol. 27(6): 336-345

doi: 10.18176/jiaci.0199

\section{Abstract}

Drug hypersensitivity reactions (DHRs) are unpredictable, complex responses to medicines in predisposed individuals. They represent a major health problem owing to the number of patients affected and the severity of the clinical conditions they can induce. In addition to environmental factors, the underlying mechanisms of DHRs are also influenced by genetic factors, although considerable gaps remain in our knowledge. Therefore, further study of the genetics of DHRs is necessary to shed light on their underlying mechanisms. In this manuscript, we provide an update on the genetic basis of the most frequent types of DHRs, including those mediated by immunological and nonimmunological mechanisms. For the first group, we will focus on immediate reactions to $\beta$-lactam antibiotics, which are associated mainly with the IgE pathway (IL13, IL4R, LGALS3, and NOD2) and antigen presentation (HLA-DRA), and nonimmediate reactions to allopurinol, anticonvulsants, antibiotics, and antiretrovirals, which are often associated with polymorphisms in the HLA system. For the second group, we will focus on nonsteroidal anti-inflammatory drugs, which are mostly associated with genetic variants in enzymes and receptors from the arachidonic acid pathway (eg, ALOX5, ALOX5AP, PTGDR, and CYSLTR 1). The information provided here will be of interest for medical practitioners from a range of disciplines who come across these reactions in their clinical practice, as well as for allergologists. Key words: Drug hypersensitivity. Immunologically-mediated reactions. Cross-hypersensitivity. Single-nucleotide polymorphisms. Genomewide association study.

\section{Resumen}

Las reacciones de hipersensibilidad a fármacos (RHFs) son respuestas no predecibles que se producen en algunos sujetos y que representan un serio problema de salud pública debido al número de pacientes implicados y a su potencial gravedad. Además de factores ambientales, en estas reacciones también participan factores genéticos, cuya influencia está, en la mayoría de los casos, aún por dilucidar. En este manuscrito describiremos la información disponible sobre la base genética de los tipos más frecuentes de RHFs, tanto de las mediadas inmunológicamente como de aquellas en las que no se requiere reconocimiento antigénico. En el primer grupo nos ocuparemos de las reacciones inmediatas a antibióticos $\beta$-lactámicos, que han sido asociadas con variantes relacionadas con la IgE (IL 13, IL4R, LGALS3 y NOD2) y la presentación antigénica (HLA-DRA), y de las reacciones no inmediatas a diferentes grupos de medicamentos (alopurinol, anticonvulsivos, antibióticos y antiretrovirales), relacionadas fundamentalmente con polimorfismos en el sistema $H L A$. En el segundo grupo nos centraremos en las reacciones inducidas por antiinflamatorios no esteroideos (AINE), que han sido asociadas básicamente con variantes en enzimas y receptores de la vía del ácido araquidónico (ALOX5, ALOX5AP, PTGDR y CYSLTR 1, entre otros). Esta revisión puede ser de interés no sólo para alergólogos, sino para los profesionales de otras disciplinas que se enfrentan a este tipo de reacciones en el desarrollo de su práctica clínica.

Palabras clave: Hipersensibilidad a fármacos. Reacciones inmunológicas. Hipersensibilidad cruzada. Polimorfismos de un único nucleótido. Estudios de asociación de genoma completo. 


\section{Introduction}

Drug hypersensitivity reactions (DHRs) are unpredictable, dose-independent responses to drugs that can be triggered by immunological (allergic) or nonimmunological (nonallergic) mechanisms $[1,2]$. Depending on the time interval between drug intake and the development of clinical symptoms, they can be classified as immediate (within the first hour) or nonimmediate (onset after more than 1 hour) [2]. The first are induced by specific IgE antibodies and encompass multiple clinical entities such as urticaria, angioedema, and anaphylaxis, with $\beta$-lactam (BL) antibiotics being the most frequent triggers. The second are induced by $\mathrm{T}$ cells and comprise a variety of conditions including potentially life-threatening conditions such as Stevens-Johnson syndrome/toxic epidermal necrolysis (SJS/TEN) [2-4]. Nonimmediate reactions are heterogeneous and can be induced by a wide range of drugs, including the antihyperuricemic agent allopurinol, anticonvulsants, antibiotics, and antiretrovirals [4].

The most common triggers of DHRs are nonsteroidal anti-inflammatory drugs (NSAIDs) [5], one of the most highly consumed classes of drugs worldwide [6]. NSAIDs can induce organ-specific toxicity [7] and immunological reactions based on specific $\operatorname{IgE}$ antibodies and $\mathrm{T}$ cells, although they mostly induce nonallergic reactions collectively known as cross-reactive hypersensitivity $[5,8,9]$. Despite the frequency of cross-reactive hypersensitivity, its molecular basis remains elusive. It has been proposed that the inhibition of cyclooxygenase (COX) 1 shunts arachidonic acid metabolism from the prostaglandin pathway towards the biosynthesis of cysteinyl-leukotrienes (Cys-LTs) (LTE4, LTC4, and LTE4), which are responsible for eliciting the hypersensitivity response in predisposed individuals [8]. The 3 clinical phenotypes currently recognized by the European Academy of Allergy and Clinical Immunology are as follows: (i) NSAIDs-exacerbated respiratory disease (NERD), in patients with rhinitis and/or asthma with or without nasal polyposis; (ii) NSAIDs-exacerbated cutaneous disease (NECD), in patients with underlying chronic spontaneous urticaria; and (iii) NSAIDs-induced urticaria/angioedema (NIUA), in otherwise healthy individuals [9].

DHRs are a crucial health problem, affecting patients of all ages. They comprise multiple complex responses to drugs resulting from a combination of environmental and genetic interactions and cannot be detected or predicted before postmarketing surveillance. Experimental models have not been developed, and despite recent progress, our understanding of the molecular and genetic mechanisms of these reactions remains limited. Consequently, we are far from identifying clinically proven genetic biomarkers. Additional associated difficulties in the study of these reactions include ethnic variation, differences in the definition of clinical phenotypes between different groups, and noninclusion of additional populations for replication purposes in most studies [10,11].

In this manuscript, we provide recent updates on the genetics of DHRs, focusing on 3 different models: ( $i)$ immediate allergic reactions to BLs; (ii) nonimmediate allergic reactions to allopurinol, anticonvulsants, antibiotics, and antiretrovirals; and (iii) cross-hypersensitivity to NSAIDs. The information provided here will be of interest not only for allergologists, but also for other health care professionals who manage these reactions in their daily practice.

\section{Allergic Reactions to Drugs}

\section{Immediate Reactions to BL Antibiotics}

Most studies have focused on the IgE/IL4-IL13 axis. Two single-nucleotide polymorphisms (SNPs) in IL13 (-1055C $>$ T and R130Q) and 2 SNPs in the $\alpha$-chain of the IL4 receptor gene (IL4RA, I50V and Q551R) have been associated with these reactions in an Italian population. The authors also showed that total IgE levels were influenced by the IL13 RQ/ QQ and $I L 4 R$ 551QQ epistatic genotype [12]. We found that the IL4RA I50V and Q551R variants were also associated with immediate BL allergy in Spanish patients and that atopy may be influenced by them [13]. In fact, both IL $4 R$ I50V and LACTB $1523 \mathrm{~A}>\mathrm{G}$ were associated with $\mathrm{IgE}$ antibodies to prevalent inhalant allergens [13].

We also recently reported that immediate allergic reactions to BLs were associated with the rs 11125 variant in the gene coding for the $\beta$-galactoside-binding lectin galectin-3, $L G A L S 3$, in 2 independent populations from Spain and Italy [14]. This secretory protein binds to IgE and FceRI on the cell membrane of B lymphocytes and mast cells and has a role in mediator release from IgE-sensitized mast cells and basophils and also in T-cell function [14].

An association between STAT6 variants and allergy to penicillin has been reported for Chinese patients [15], and this may be related to the role of this gene in $\operatorname{IgE}$ synthesis. However, a study performed in Spain found no association between STAT6 and BL allergy [13].

Italian patients with immediate allergy to BLs carrying the minor allele of the $-308 \mathrm{G}>\mathrm{A}$ variant in TNFA showed higher specific IgE levels [16]. It has been hypothesized that this association could be related to antigen presentation, as this polymorphism is part of an extended HLA-A1-B8-DR3-DQ2 haplotype and influences gene expression [17]. An association between cytokine SNPs and BL allergy has also been reported for $I L 10[18,19]$ and $I L 18$ [20].

The promoter variant $-109 \mathrm{~T}>\mathrm{C}$ in FCER $1 B$ has been suggested as a potential genetic susceptibility factor for increased $\operatorname{IgE}$ levels to cephalosporins in occupational allergy [19], and an SNP in E237G has been associated with penicillin allergy in Chinese patients [20].

SNPs in the genes for nucleotide-binding oligomerization domain 1 and 2 (NOD1 and NOD2) have been associated with atopy and high serum total IgE [21,22]. Carriers of the rs2066845 variant in the leucine-rich repeat domain of NOD2 presented a lower risk of immediate reactions to BLs in an Italian population; carriers of the WT/insC genotype of rs5743293 presented a higher risk of reaction in Spanish patients [23]. As NOD2 is related to inflammation and allergy, these findings could indicate a relationship between immediate BL allergy and atopy and/or inflammation [23]. All the aforementioned studies were performed according to a candidate gene approach on the basis of biological plausibility 
criteria. We recently published the only available genomewide fine-mapping genotyping study, which was based on 2 independent populations from Spain and Italy [24]. We found that the rs7192 and rs8084 variants in the HLA-DRA gene were associated with a positive skin test response to amoxicillin and penicillin but not to cephalosporins. We hypothesize that these SNPs could have a role in the presentation of BL-derived antigenic motifs through changes in the 3 -dimensional structure of the MHC $\alpha / \beta$ chains [24]. In addition, an association was found between BL allergy and 2 variants in the $H L A-D R A / H L A-D R B 5$ region (rs7754768 and rs9268832) [24]. Our results agree with those of various studies showing a link between increased IgE levels and HLA alleles [30,31] and a potential effect of NOD2 polymorphisms on HLA-DRA expression [32,33]. Our genome-wide study also revealed that the $\mathrm{C} 5$ missense variant rs 17612 predicted BL allergy in both populations, albeit to a lower extent in the Italian patients [24]. The ZNF300 SNP rs4958427 was associated with immediate reactions to $\mathrm{BL}$ in the Spanish population but not in the Italian population. This gene encodes a transcription factor involved in the NF- $\kappa \mathrm{B}$ signaling pathway and could have an effect on $H L A-D R A$ expression [25]. In addition, this gene, together with NOD1 and NOD2, has been strongly associated with inflammation in Crohn disease [26].

\section{Nonimmediate Reactions}

Most genetic associations with nonimmediate DHRs have been found for alleles from the HLA system. This type of DHR can induce a wide variety of clinical manifestations, from mild reactions such as urticaria and maculopapular exanthema, to potentially life-threatening conditions such as SJS/TEN and drug-induced liver injury. In this section, we focus on the genetics of reactions induced by allopurinol, anticonvulsants, antibiotics, and antiretrovirals, as these agents are the most frequent triggers of such reactions.

\section{Allopurinol}

Evidence for an association between allopurinol-induced SJS/TEN and the HLA-B*5801 allele has been consistently reported in various populations [27-31]. This allele is also a risk factor for other severe and mild DHRs in Han Chinese patients [32]. Thus, screening for the $H L A-B * 5801$ allele has been proposed to reduce the incidence of these nonimmediate DHRs [33-35]. Another promising approach is to genotype the rs9263726 variant in psoriasis susceptibility 1 candidate 1 gene as a surrogate marker [36] that is in absolute linkage disequilibrium with $H L A-B * 5801$ [37].

\section{Anticonvulsants}

Multiple studies have found an association between the $H L A-B * 1502$ allele and carbamazepine-induced SJS/TEN in Han Chinese [38-41] and other Asian populations [42-45]. The strength of such associations has led to the recommendation to screen for this variant in patients with Asian ancestry before starting treatment $[46,47]$. However, other studies have failed to find such associations in Japan $[48,49]$ and Europe $[50,51]$. In Han Chinese and Thai populations, the
$H L A-B * 1502$ allele has also been associated with phenytoininduced SJS/TEN [40,42] and oxcarbazepine-induced SJS/ TEN [52]. In the latter study, the severity and incidence of oxcarbazepine-induced SJS/TEN were less pronounced than that induced by carbamazepine [52]. The $H L A-A * 3101$ allele has been associated with cutaneous adverse drug reactions induced by carbamazepine [53] and proposed as a universal risk marker for these reactions in a recent meta-analysis [54]. The $H L A-B * 40: 02$ and $D R B 1 * 04: 03$ alleles have also been shown to be risk factors for oxcarbazepine-induced maculopapular eruption [55].

In a Han Chinese population of patients with SJS/TEN, the $H L A-A * 24: 02$ allele was associated not only with the general aromatic epileptic drug group, but also with individual drugs (carbamazepine, lamotrigine, and phenytoin) [41]. In addition, this allele was more frequent in cases with maculopapular exanthema than in controls [41].

It was recently reported that carrier rates of $H L A-A * 01$ and $H L A-B * 13: 01$ among Thai children were significantly higher in patients with severe cutaneous DHRs induced by phenobarbital than in tolerant controls [56].

The $H L A-B * 13: 01, H L A-B * 56: 02 / 04$, and $C Y P 2 C 19 * 3$ alleles have been reported to be major risk factors for drug hypersensitivity syndrome [57]. The authors also showed that carrying the $C Y P 2 C 19 * 3$ variant and having Chinese ancestry were significant risk factors for SJS/TEN [57].

Other associations related to the HLA system include the alleles $A * 68: 01, D R B 1 * 13: 01$, and $D R B 1 * 01$ in the case of lamotrigine-induced SJS/TEN and the $B * 58: 01$ allele in lamotrigine-induced hypersensitivity syndrome [58].

\section{Antibiotics}

Sulphamethoxazole-induced SJS/TEN has been strongly associated with 3 HLA alleles $(A * 29, B * 12$, and $D R 7)$ [59], a phenotype that was further associated with the $\mathrm{B} * 38$ allele [59]. Other associations include the alleles $A * 30, B^{*} 13$, and $C w 6$ in cotrimoxazole-induced fixed drug eruption [60], and the alleles $A 2$ and Drw52 in aminopenicillin-induced hypersensitivity syndrome [61].

\section{Antiretrovirals}

The association between the $H L A-B * 57: 01$ and nonimmediate allergy to abacavir has been reported in Australian [62], Caucasian [63-65], and African-American patients [66]; the co-occurrence of this variant with the Hsp70-Hom M493T allele is considered necessary for the development of hypersensitivity reactions to this drug [67]. The utility of $H L A-B * 57: 01$ allele testing to reduce the frequency of abacavir-induced hypersensitivity was recently highlighted [68].

The HLA allele $D R B 1 * 01$ has been linked to nevirapineinduced maculopapular exanthema in Caucasians [69], as well as to hypersensitivity syndrome and SJS/TEN [70]. Associations between nevirapine-induced DHRs and the $B * 35: 05$ allele have been reported in Thailand and India $[71,72]$. Other $H L A$ associations have been found for the alleles $C w 8, B 14$ [70], $C w 8$ [71], and $C w^{*} 04[73,74]$. 


\section{Nonallergic Reactions to Drugs: Hypersensitivity to NSAIDS}

Most genetic association studies have followed the gene candidate approach, focusing on NERD [75,76], even though NIUA is the clinical entity most frequently induced by drug hypersensitivity [5]. They have mainly been performed in populations with Asian ancestry and include a limited number of patients, generally without a second population for replication $[11,75,76]$.

Given the proposed role of COX-1 inhibition in this condition and the subsequent production of CysLTs [77,78], most genetic studies have targeted genes encoding enzymes and receptors involved in the metabolism of arachidonic acid, although other studies have evaluated cytokines and other mediator genes. In recent years, 3 genome-wide association studies (GWAS) on cross-hypersensitivity to NSAIDs have also been published.

\section{Enzyme and Receptor Genes From the Arachidonic Acid Metabolic Pathway}

The minor allele of the promoter variant rs730012 $(-444 \mathrm{~A}>\mathrm{C})$ in the leukotriene C4 synthase gene (LTC4S) was shown to be more frequent in NERD patients than in ASA-tolerant asthmatics and healthy individuals in a Polish study [79]. Interestingly, the authors reported increased expression of LTC4S in eosinophils [79], which has also been observed in bronchial biopsies from NERD patients [80,81]. However, these findings have not always been replicated in other populations [82-85]. The minor allele frequency (MAF) of this SNP was also found to be higher for NECD patients in Poland [86], but not for patients with NSAID-induced angioedema in Spain [87]. Furthermore, in a Spanish study including the largest number of cross-hypersensitivity patients published to date, we were unable to find an association between the rs730012 variant and NIUA [88]. The variants rs5789 and rs10306135 in prostaglandin-endoperoxide synthase 1 (COX-1 gene) were shown to be associated with NERD [89]. However, more studies are required to further establish the potential role of cyclooxygenase variants in NSAID-induced cross-hypersensitivity [90].

With respect to lipoxygenase enzymes, a particular haplotype in the promoter of arachidonate 5-lipoxygenase ( $A L O X 5)$ has been shown to be more frequent in NERD patients in a Korean study [84]. We found that the rs1132340 SNP in $A L O X 5$ activating protein was associated with NIUA [88], an association that was not found in NERD patients in Korea [84]. In another Spanish study, no association was found with the $A L O X 5$ rs4948672 SNP in NIUA patients [91]. As for $A L O X 15$, we found a statistically significant association between the promoter variant $-272 \mathrm{C}>\mathrm{A}$ (rs7220870) and NIUA in 2 independent populations from Spain [88], although this association was not found in Korean patients [92]. We recently reported an association between the rs3892408 ALOX15 genetic variant and Spanish NERD patients [89].

Another Spanish study found an association between the rs6962291 variant in thromboxane A synthase 1 (TBXAS1) and NIUA [91]. Interestingly, this polymorphism was protective in Korean NERD patients [93]. Statistically significant associations have been found for prostaglandin receptor PGER1-4 and PGGIR gene polymorphisms in NERD [94,95]. We previously reported associations for 2 SNPs in $P G E 1 R$ (rs3810253 and rs3810255) and 1 in PGER2 (rs1254598) [88] in NIUA, neither of which was found in Asian NERD patients [94]. The MAF of PTGER4 $-1254 \mathrm{G}>\mathrm{A}$ was recently found to be higher in NECD patients than in healthy individuals [96]. Finally, the rs 8004654 polymorphism in $P G D R$ was shown to be significantly associated with NIUA in 2 independent Spanish populations [88], as well as in American asthmatics [97].

We also explored the presence of copy number variations in ALOX5 and PTGER1 in NIUA patients and showed that this type of genetic variation may also play a role [98]; future research should focus on this area.

With respect to CysLT receptors, 3 promoter SNPs in the CysLT receptor 1 gene (CYSLTR1) $(-634 \mathrm{C}>\mathrm{T},-475 \mathrm{~A}>\mathrm{C}$, and $-336 \mathrm{~A}>\mathrm{G}$ ) have been associated with NERD $[95,99]$. We have also shown the rs320995 synonymous polymorphism CYSLTR1 to be associated with NIUA [88]. This variant has been associated with urinary LTE4 levels in asthmatics [100] and inconsistently with NERD, asthma, and lung function [99,101-103]. Interestingly, this polymorphism is in strong linkage disequilibrium with a promoter variant that affects transcription [99]. Variants in CYSLTR2 that influence gene expression have been associated with NERD [104], although the SNPs rs912277 and rs912278 in CYSLTR2 were not found to be associated with NIUA [88].

The TBXA2 receptor $(T B X A 2 R)$ variant $-4684 \mathrm{~T}>\mathrm{C}$ was recently shown to be associated with NIUA when compared with healthy individuals but not with NECD in Korea [105], whereas other TXBA2R SNPs were not associated with NIUA in Spanish patients [91]. Finally, the MAF of the 795T $>C$ $T B X A 2 R$ variant has also been found to be higher in NERD than in ASA-tolerant asthmatics [106].

\section{Other Variants Outside Eicosanoid Biosynthesis}

We also recently reported nominal associations for 2 SNPs (rs1816678 and rs764917) in the thymic stromal lymphopoietin gene, although these results were not statistically significant after multiple testing [107].

The histamine N-methyltransferase $939 \mathrm{~A}>\mathrm{G}$ polymorphism has been associated with NECD [108], suggesting that histamine-related genetic variants could have a role in crosshypersensitivity to NSAIDs, as occurs in allergies and other diseases [109]. However, in a previous study we did not find associations between NSAID-induced hypersensitivity and common SNPs for 3 histamine receptors [110], although we did find that the diamine oxidase (histaminase) missense polymorphism rs10156191 (Thr16Met), which affects histamine metabolism, was associated with NIUA and NERD [111]. The histaminase $8956 \mathrm{C}>\mathrm{G}$ variant was shown to be associated with NIUA in a Brazilian population [112]. We recently found associations between NIUA and several polymorphisms in genes involved in mast cell activation: rs12746200 (PLA2G4A), rs2228246 (PLCG1), and rs1805034 (TNFRS11A) [113].

Interestingly, 2 intronic polymorphisms in gasdermin B (rs870830 and rs7216389), both of which belong to a family 
of genes related to epithelial cell apoptosis, showed statistically significant associations with NERD and with $\mathrm{FEV}_{1}$ in a Korean population [114]. However, the molecular mechanisms underlying these associations remain unknown.

Considering that the underlying mechanism in crosshypersensitivity to NSAIDs has been considered to be pharmacological, one might expect that genetic variants in drug metabolism enzymes could also have a role [115]. Nevertheless, a recent study failed to show an association between 2 SNPs in the cytochrome P450 family (CYP2C9 and CYP2C19) and cross-hypersensitivity [116].

Finally, further associations have been found with the adenosine receptor $\mathrm{A} 3$ gene $(-1050 \mathrm{G}>\mathrm{T}$ and $-564 \mathrm{C}>\mathrm{T})$ [117], IL4 $(-589 \mathrm{~T}>\mathrm{C})$ [112,118], IL10 $(-1082 \mathrm{G}>\mathrm{A})$ [112], CTLA $(49 \mathrm{~A}>\mathrm{G})$ [112], nitric oxide synthase 2 [119], and the HLA system [120-122].

\section{Beyond the Candidate Gene Approach}

The first GWAS in NSAID-induced cross-hypersensitivity was performed in Korean patients with NERD. The authors found an intriguing association between the decline in $\mathrm{FEV}_{1}$ and a nonsynonymous polymorphism (rs7572857, Gly74Ser) in centrosomal protein of $68 \mathrm{Kd}$ (CEP68) [123], a gene involved in centrosomal cohesion and epidermal growth factor signaling [124,125]. Our group evaluated 53 common SNPs in this gene in a population of Spanish patients presenting NIUA, NERD, and blended reactions [126]. Seventeen variants showed evidence of association with NIUA, including the SNP rs7572857. Moreover, 8 of these polymorphisms were also marginally associated with NERD and blended reactions [126]. Although our findings suggest a role for CEP68 in crosshypersensitivity to NSAIDs, the molecular basis for these associations requires further elucidation.

In another GWAS of NERD in Korean patients, the most relevant susceptibility variant was $H L A-D P B 1$ rs 1042151 (Met105Val) [127]. Interestingly, a recently published study showed that the variant rs3128965, which is in perfect linkage disequilibrium with rs3128965, was also associated with NERD in Korean patients [128].

We recently conducted the only GWAS for NIUA using 2 independent populations from Spain and Taiwan [129]. Suggestive associations were found for 3 genetic clusters in the Spanish group (RIMS1, BICC1, and RAD51L1) and 1 region in the Han Chinese group (ABI3BP). Most of these regions are linked to the $\mathrm{Ca} 2^{+}$, cAMP, and/or P53 signaling pathways [129].

\section{Conclusion}

The complexity of environment-gene interactions could explain, at least in part, why there is often a lack of reproducibility of genetic association studies in DHRs in different countries. Most candidate gene studies have associated immediate BL allergy with IgE class switching, whereas the only available GWAS has highlighted the role of the HLA system. Different alleles from this system have been associated with nonimmediate DHRs in a number of studies. Most studies on NSAID-induced cross-hypersensitivity have focused on arachidonic acid pathways, and associations in related genes have been reported. Unfortunately, despite recent advances, we are still some way from fully characterizing the underlying genetics of DHRs and risk factors and, consequently, from uncovering their pathogenic mechanisms. More studies are necessary, as is agreement between groups and countries regarding definitions of phenotypes in the broad spectrum of DHRs.

\section{Acknowledgments}

JA Cornejo-García is a researcher from the Miguel Servet Program (Ref CP14/00034); JR Perkins is a researcher from the Sara Borrell Program (Ref CD14/00242). Both programs are from the Carlos III National Health Institute, Spanish Ministry of Economy and Competitiveness.

\section{Funding}

This study was supported by grants cofunded by the European Regional Development Fund (ERDF), from the Carlos III National Health Institute (ARADyAL network RD16/0006/0001, RD16/0006/004, RD16/0006/0019, and PI15/00303), the Health Government of Andalusia (PI-04632013), and Junta de Extremadura (IB16170).

\section{Conflicts of Interest}

The authors declare that they have no conflicts of interest.

\section{References}

1. Johansson SG, Hourihane JO, Bousquet J, Bruijnzeel-Koomen C, Dreborg S, Haahtela T, et al. A revised nomenclature for allergy. An EAACl position statement from the EAACI nomenclature task force. Allergy. 2001;56(9):813-24.

2. Romano A, Demoly P. Recent advances in the diagnosis of drug allergy. Curr Opin Allergy Clin Immunol. 2007;7(4):299-303.

3. Blanca M, Romano A, Torres MJ, Fernandez J, Mayorga C, Rodriguez $J$, et al. Update on the evaluation of hypersensitivity reactions to betalactams. Allergy. 2009;64(2):183-93.

4. Roujeau JC, Haddad C, Paulmann M, Mockenhaupt M. Management of nonimmediate hypersensitivity reactions to drugs. Immunol Allergy Clin North Am. 2014;34(3):473-87.

5. Dona I, Blanca-Lopez N, Torres MJ, Garcia-Campos J, GarciaNunez I, Gomez F, et al. Drug hypersensitivity reactions: response patterns, drug involved, and temporal variations in a large series of patients. J Investig Allergol Clin Immunol. 2012;22(5):363-71.

6. Conaghan PG. A turbulent decade for NSAIDs: update on current concepts of classification, epidemiology, comparative efficacy, and toxicity. Rheumatol Int. 2012;32(6):1491-502.

7. Agundez JA, Lucena MI, Martinez C, Andrade RJ, Blanca M, Ayuso $\mathrm{P}$, et al. Assessment of nonsteroidal anti-inflammatory drug-induced hepatotoxicity. Expert Opin Drug Metab Toxicol. 2011;7(7):817-28

8. Cornejo-Garcia JA, Blanca-Lopez N, Dona I, Andreu I, Agundez JA, Carballo $M$, et al. Hypersensitivity reactions to non-steroidal anti-inflammatory drugs. Curr Drug Metab. 2009;10(9):971-80. 
9. Kowalski ML, Asero R, Bavbek S, Blanca M, Blanca-Lopez N, Bochenek $\mathrm{G}$, et al. Classification and practical approach to the diagnosis and management of hypersensitivity to nonsteroidal anti-inflammatory drugs. Allergy. 2013;68(10):1219-32.

10. Cornejo-Garcia JA, Jurado-Escobar R, Dona I, Perkins JR, Agundez JA, Garcia-Martin E, et al. The Genetics of Drug Hypersensitivity Reactions. J Investig Allergol Clin Immunol. 2016;26(4):222-32

11. Oussalah A, Mayorga C, Blanca M, Barbaud A, Nakonechna A, Cernadas J, et al. Genetic variants associated with drugsinduced immediate hypersensitivity reactions: a PRISMAcompliant systematic review. Allergy. 2016;71(4):443-62.

12. Gueant-Rodriguez RM, Romano A, Beri-Dexheimer M, Viola M, Gaeta F, Gueant JL. Gene-gene interactions of IL13 and IL4RA variants in immediate allergic reactions to betalactam antibiotics. Pharmacogenet Genomics. 2006;16(10):713-9.

13. Cornejo-Garcia JA, Gueant-Rodriguez RM, Torres MJ, BlancaLopez N, Tramoy D, Romano A, et al. Biological and genetic determinants of atopy are predictors of immediate-type allergy to betalactams, in Spain. Allergy. 2012;67(9):1181-5.

14. Cornejo-Garcia JA, Romano A, Gueant-Rodriguez RM, Oussalah A, Blanca-Lopez N, Gaeta F, et al. A nonsynonymous polymorphism in galectin-3 lectin domain is associated with allergic reactions to beta-lactam antibiotics. Pharmacogenomics J. 2016;16(1):79-82.

15. Huang CZ, Zou D, Yang J, Qiao HL. Polymorphisms of STAT6 and specific serum IgE levels in patients with penicillin allergy. Int J Clin Pharmacol Ther. 2012;50(7):461-7.

16. Gueant-Rodriguez RM, Gueant JL, Viola M, Tramoy D, Gaeta F, Romano A. Association of tumor necrosis factoralpha -308G $>$ A polymorphism with IgE-mediated allergy to betalactams in an Italian population. Pharmacogenomics $J$. 2008;8(2):162-8.

17. Wilson AG, de Vries N, Pociot F, di Giovine FS, van der Putte LB, Duff GW. An allelic polymorphism within the human tumor necrosis factor alpha promoter region is strongly associated with HLA A1, B8, and DR3 alleles. J Exp Med. 1993;177(2):557-60.

18. Guglielmi L, Fontaine C, Gougat C, Avinens O, Eliaou JF, Guglielmi P, et al. IL-10 promoter and IL4-Ralpha gene SNPs are associated with immediate beta-lactam allergy in atopic women. Allergy. 2006;61(8):921-7.

19. Qiao HL, Wen Q, Gao N, Tian X, Jia LJ. Association of IL-10 level and IL-10 promoter SNPs with specific antibodies in penicillinallergic patients. Eur J Clin Pharmacol. 2007;63(3):263-9.

20. Ming L, Wen Q, Qiao HL, Dong ZM. Interleukin-18 and IL18 $-607 \mathrm{~A} / \mathrm{C}$ and $-137 \mathrm{G} / \mathrm{C}$ gene polymorphisms in patients with penicillin allergy. J Int Med Res. 2011;39(2):388-98.

21. Kabesch M, Peters W, Carr D, Leupold W, Weiland SK, von Mutius E. Association between polymorphisms in caspase recruitment domain containing protein 15 and allergy in two German populations. J Allergy Clin Immunol. 2003;111(4):813-7.

22. Weidinger S, Klopp N, Rummler L, Wagenpfeil S, Baurecht HJ, Gauger A, et al. Association of CARD15 polymorphisms with atopy-related traits in a population-based cohort of Caucasian adults. Clin Exp Allergy. 2005;35(7):866-72.

23. Bursztejn $A C$, Romano $A$, Gueant-Rodriguez RM, Cornejo JA, Oussalah A, Chery $C$, et al. Allergy to betalactams and nucleotide-binding oligomerization domain (NOD) gene polymorphisms. Allergy. 2013;68(8):1076-80.
24. Gueant JL, Romano A, Cornejo-Garcia JA, Oussalah A, Chery C, Blanca-Lopez N, et al. HLA-DRA variants predict penicillin allergy in genome-wide fine-mapping genotyping. J Allergy Clin Immunol. 2015;135(1):253-9.

25. Wang $T$, Wang $X G, X u J H$, Wu XP, Qiu $H L$, Yi $H$, et al Overexpression of the human ZNF300 gene enhances growth and metastasis of cancer cells through activating NF-kB pathway. J Cell Mol Med. 2012;16(5):1134-45.

26. Parkes M, Barrett JC, Prescott NJ, Tremelling M, Anderson CA, Fisher SA, et al. Sequence variants in the autophagy gene IRGM and multiple other replicating loci contribute to Crohn's disease susceptibility. Nat Genet. 2007;39(7):830-2.

27. Hung SI, Chung WH, Liou LB, Chu CC, Lin M, Huang HP, et al. HLA-B ${ }^{*} 5801$ allele as a genetic marker for severe cutaneous adverse reactions caused by allopurinol. Proc Natl Acad Sci U SA. 2005;102(11):4134-9.

28. Tassaneeyakul W, Jantararoungtong T, Chen P, Lin PY, Tiamkao $S$, Khunarkornsiri $U$, et al. Strong association between HLA-B*5801 and allopurinol-induced Stevens-Johnson syndrome and toxic epidermal necrolysis in a Thai population. Pharmacogenet Genomics. 2009;19(9):704-9.

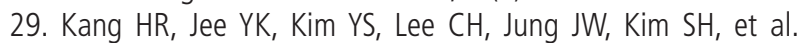
Positive and negative associations of HLA class I alleles with allopurinol-induced SCARs in Koreans. Pharmacogenet Genomics. 2011;21(5):303-7.

30. Somkrua R, Eickman EE, Saokaew S, Lohitnavy $M$, Chaiyakunapruk N. Association of HLA-B*5801 allele and allopurinol-induced Stevens Johnson syndrome and toxic epidermal necrolysis: a systematic review and meta-analysis. BMC Med Genet. 2011;12:118.

31. Goncalo M, Coutinho I, Teixeira V, Gameiro AR, Brites MM, Nunes $R$, et al. HLA-B*58:01 is a risk factor for allopurinolinduced DRESS and Stevens-Johnson syndrome/toxic epidermal necrolysis in a Portuguese population. Br J Dermatol. 2013;169(3):660-5.

32. Cao ZH, Wei ZY, Zhu QY, Zhang JY, Yang L, Qin SY, et al. $H L A-B * 58: 01$ allele is associated with augmented risk for both mild and severe cutaneous adverse reactions induced by allopurinol in Han Chinese. Pharmacogenomics. 2012;13(10):1193-201.

33. Park DJ, Kang JH, Lee JW, Lee KE, Wen L, Kim TJ, et al. Costeffectiveness analysis of HLA-B5801 genotyping in the treatment of gout patients with chronic renal insufficiency in Korea. Arthritis Care Res. 2015;67(2):280-7.

34. SaokaewS, TassaneeyakulW, Maenthaisong R, Chaiyakunapruk $N$. Cost-effectiveness analysis of $H L A-B * 5801$ testing in preventing allopurinol-induced SJS/TEN in Thai population. PloS One. 2014;9(4):e94294.

35. Ko TM, Tsai CY, Chen SY, Chen KS, Yu KH, Chu CS, et al. Use of HLA-B*58:01 genotyping to prevent allopurinol induced severe cutaneous adverse reactions in Taiwan: national prospective cohort study. BMJ. 2015;351:h4848.

36. Maekawa K, Nishikawa J, Kaniwa N, Sugiyama E, Koizumi $T$, Kurose $K$, et al. Development of a rapid and inexpensive assay for detecting a surrogate genetic polymorphism of HLA-B*58:01: a partially predictive but useful biomarker for allopurinol-related Stevens-Johnson syndrome/toxic epidermal necrolysis in Japanese. Drug Metab Pharmacokinet. 2012;27(4):447-50. 
37. Tohkin M, Kaniwa N, Saito Y, Sugiyama E, Kurose $K$, Nishikawa J, et al. A whole-genome association study of major determinants for allopurinol-related Stevens-Johnson syndrome and toxic epidermal necrolysis in Japanese patients. Pharmacogenomics J. 2013;13(1):60-9.

38. Chung WH, Hung SI, Hong HS, Hsih MS, Yang LC, Ho HC, et al. Medical genetics: a marker for Stevens-Johnson syndrome. Nature. 2004;428(6982):486.

39. Hung SI, Chung WH, Jee SH, Chen WC, Chang YT, Lee WR, et al. Genetic susceptibility to carbamazepine-induced cutaneous adverse drug reactions. Pharmacogenet Genomics. 2006;16(4):297-306.

40. Man CB, Kwan P, Baum L, Yu E, Lau KM, Cheng AS, et al. Association between HLA-B*1502 allele and antiepileptic drug-induced cutaneous reactions in Han Chinese. Epilepsia. 2007;48(5):1015-8.

41. Shi YW, Min FL, Zhou D, Qin B, Wang J, Hu FY, et al. HLA-A*24:02 as a common risk factor for antiepileptic drug-induced cutaneous adverse reactions. Neurology. 2017;88(23):2183-91.

42. Locharernkul C, Loplumlert J, Limotai C, Korkij W, Desudchit T, Tongkobpetch $\mathrm{S}$, et al. Carbamazepine and phenytoin induced Stevens-Johnson syndrome is associated with HLA-B*1502 allele in Thai population. Epilepsia. 2008;49(12):2087-91.

43. Hsiao YH, Hui RC, Wu T, Chang WC, Hsih MS, Yang CH, et al. Genotype-phenotype association between HLA and carbamazepine-induced hypersensitivity reactions: strength and clinical correlations. J Dermatol Sci. 2014;73(2):101-9.

44. Aggarwal R, Sharma M, Modi M, Garg VK, Salaria M. HLA-B*1502 is associated with carbamazepine induced Stevens-Johnson syndrome in North Indian population. Hum Immunol. 2014;75(11):1120-2.

45. Nguyen DV, Chu HC, Nguyen DV, Phan MH, Craig T, Baumgart $K$, et al. HLA-B*1502 and carbamazepine-induced severe cutaneous adverse drug reactions in Vietnamese. Asia Paci Allergy. 2015;5(2):68-77.

46. Tangamornsuksan W, Chaiyakunapruk N, Somkrua R, Lohitnavy M, Tassaneeyakul W. Relationship between the HLA-B*1502 allele and carbamazepine-induced Stevens-Johnson syndrome and toxic epidermal necrolysis: a systematic review and metaanalysis. JAMA Dermatol. 2013;149(9):1025-32.

47. Ferrell PB, Jr., McLeod HL. Carbamazepine, HLA-B*1502 and risk of Stevens-Johnson syndrome and toxic epidermal necrolysis: US FDA recommendations. Pharmacogenomics. 2008;9(10):1543-6.

48. Kaniwa N, Saito Y, Aihara M, Matsunaga K, Tohkin M, Kurose $K$, et al. HLA-B locus in Japanese patients with anti-epileptics and allopurinol-related Stevens-Johnson syndrome and toxic epidermal necrolysis. Pharmacogenomics. 2008;9(11):1617-22.

49. Ikeda H, Takahashi $Y$, Yamazaki E, Fujiwara T, Kaniwa $N$, Saito $Y$, et al. HLA class I markers in Japanese patients with carbamazepine-induced cutaneous adverse reactions. Epilepsia. 2010;51(2):297-300.

50. Lonjou C, Borot N, Sekula P, Ledger N, Thomas L, Halevy S, et al. A European study of HLA-B in Stevens-Johnson syndrome and toxic epidermal necrolysis related to five high-risk drugs. Pharmacogenet Genomics. 2008;18(2):99-107.

51. Lonjou C, Thomas L, Borot N, Ledger N, de Toma C, LeLouet $H$, et al. A marker for Stevens-Johnson syndrome .... ethnicity matters. Pharmacogenomics J. 2006;6(4):265-8.
52. Chen CB, Hsiao YH, Wu T, Hsih MS, Tassaneeyakul W, Jorns TP, et al. Risk and association of HLA with oxcarbazepineinduced cutaneous adverse reactions in Asians. Neurology. 2017;88(1):78-86.

53. Ozeki T, Mushiroda T, Yowang A, Takahashi A, Kubo M, Shirakata $Y$, et al. Genome-wide association study identifies HLA-A*3101 allele as a genetic risk factor for carbamazepineinduced cutaneous adverse drug reactions in Japanese population. Hum Mol Cenet. 2011;20(5):1034-41.

54. Grover S, Kukreti R. HLA alleles and hypersensitivity to carbamazepine: an updated systematic review with metaanalysis. Pharmacogenet Genomics. 2014;24(2):94-112.

55. Moon J, Kim TJ, Lim JA, Sunwoo JS, Byun Jl, Lee ST, et al. HLA-B*40:02 and $D R B 1{ }^{*} 04: 03$ are risk factors for oxcarbazepine-induced maculopapular eruption. Epilepsia. 2016;57(11):1879-86.

56. Manuyakorn W, Mahasirimongkol S, Likkasittipan $P$, Kamchaisatian W, Wattanapokayakit S, Inunchot W, et al. Association of HLA genotypes with phenobarbital hypersensitivity in children. Epilepsia. 2016;57(10):1610-6.

57. Yampayon K, Sukasem C, Limwongse C, Chinvarun Y, Tempark $\mathrm{T}$, Rerkpattanapipat $\mathrm{T}$, et al. Influence of genetic and nongenetic factors on phenytoin-induced severe cutaneous adverse drug reactions. Eur J Pharmacol. 2017;73(7):855-65.

58. Kazeem GR, Cox C, Aponte J, Messenheimer J, Brazell C, Nelsen AC, et al. High-resolution HLA genotyping and severe cutaneous adverse reactions in lamotrigine-treated patients. Pharmacogenet Genomics. 2009;19(9):661-5.

59. Roujeau JC, Bracq C, Huyn NT, Chaussalet E, Raffin C, Duedari N. HLA phenotypes and bullous cutaneous reactions to drugs. Tissue Antigens. 1986;28(4):251-4.

60. Ozkaya-Bayazit E, Akar U. Fixed drug eruption induced by trimethoprim-sulfamethoxazole: evidence for a link to HLA-A30 B13 Cw6 haplotype. J Am Acad Dermatol. 2001;45(5):712-7.

61. Romano $A$, De Santis $A$, Romito $A$, Di Fonso $M$, Venuti A, Gasbarrini $G B$, et al. Delayed hypersensitivity to aminopenicillins is related to major histocompatibility complex genes. Ann Allergy Asthma Immunol. 1998;80(5):433-7.

62. Mallal S, Nolan D, Witt C, Masel G, Martin AM, Moore C, et al. Association between presence of HLA-B ${ }^{*} 5701, \mathrm{HLA}-\mathrm{DR} 7$, and HLA-DQ3 and hypersensitivity to HIV-1 reverse-transcriptase inhibitor abacavir. Lancet. 2002;359(9308):727-32.

63. Hetherington $S$, Hughes $A R$, Mosteller $M$, Shortino $D$, Baker KL, Spreen W, et al. Genetic variations in HLA-B region and hypersensitivity reactions to abacavir. Lancet. 2002;359(9312):1121-2.

64. Hughes DA, Vilar FJ, Ward CC, Alfirevic A, Park BK, Pirmohamed M. Cost-effectiveness analysis of HLA B*5701 genotyping in preventing abacavir hypersensitivity. Pharmacogenetics. 2004;14(6):335-42.

65. Mallal S, Phillips E, Carosi G, Molina JM, Workman C, Tomazic J, et al. HLA-B ${ }^{*} 5701$ screening for hypersensitivity to abacavir. N Engl J Med. 2008;358(6):568-79.

66. Saag M, Balu R, Phillips E, Brachman P, Martorell C, Burman W, et al. High sensitivity of human leukocyte antigen-b*5701 as a marker for immunologically confirmed abacavir hypersensitivity in white and black patients. Clin Infect Dis. 2008;46(7):1111-8. 
67. Martin AM, Nolan D, Gaudieri S, Almeida CA, Nolan R, James I, et al. Predisposition to abacavir hypersensitivity conferred by HLA-B ${ }^{*} 5701$ and a haplotypic Hsp70-Hom variant. Proc Natl Acad Sci U S A. 2004;101(12):4180-5.

68. Small CB, Margolis DA, Shaefer MS, Ross LL. HLA-B*57:01 allele prevalence in HIV-infected North American subjects and the impact of allele testing on the incidence of abacavirassociated hypersensitivity reaction in $\mathrm{HLA}-\mathrm{B}^{*}$ 57:01-negative subjects. BMC Infect Dis. 2017;17(1):256.

69. Martin AM, Nolan D, James I, Cameron P, Keller J, Moore C, et al. Predisposition to nevirapine hypersensitivity associated with HLA-DRB 1*0101 and abrogated by low CD4 T-cell counts. AIDS. 2005;19(1):97-9.

70. Vitezica ZG, Milpied B, Lonjou C, Borot N, Ledger TN, Lefebvre $A$, et al. HLA-DRB $1{ }^{*} 01$ associated with cutaneous hypersensitivity induced by nevirapine and efavirenz. AIDS. 2008;22(4):540-1.

71. Chantarangsu S, Mushiroda T, Mahasirimongkol S, Kiertiburanakul S, Sungkanuparph S, Manosuthi W, et al. HLA-B*3505 allele is a strong predictor for nevirapineinduced skin adverse drug reactions in HIV-infected Thai patients. Pharmacogenet Genomics. 2009;19(2):139-46.

72. Umapathy S, Pawar A, Bajpai S, Pazare AR, Ghosh K. HLA involvement in nevirapine-induced dermatological reaction in antiretroviral-treated HIV-1 patients. J Pharmacol Pharmacother. 2011;2(2):114-5.

73. Likanonsakul S, Rattanatham T, Feangvad S, Uttayamakul S, Prasithsirikul W, Tunthanathip P, et al. HLA-CW*04 allele associated with nevirapine-induced rash in HIV-infected Thai patients. AIDS Res Ther. 2009:6:22.

74. Gao S, Gui XE, Liang K, Liu Z, Hu J, Dong B. HLA-dependent hypersensitivity reaction to nevirapine in Chinese Han HIV-infected patients. AIDS Res Hum Retroviruses. 2012;28(6):540-3.

75. Gomez F, Perkins JR, Garcia-Martin E, Canto G, Cornejo-Garcia JA. Genetic basis of hypersensitivity reactions to nonsteroidal anti-inflammatory drugs. Curr Opin Allergy Clin Immunol. 2015;15(4):285-93.

76. Pham DL, Kim JH, Trinh TH, Park HS. What we know about nonsteroidal anti-inflammatory drug hypersensitivity. Korean J Intern Med 2016;31(3):417-32.

77. Vane JR. Inhibition of prostaglandin synthesis as a mechanism of action for aspirin-like drugs. Nat New Biol. 1971:231(25):232-5

78. Sladek K, Szczeklik A. Cysteinyl leukotrienes overproduction and mast cell activation in aspirin-provoked bronchospasm in asthma. Eur Respir J. 1993;6(3):391-9.

79. Sanak M, Pierzchalska M, Bazan-Socha S, Szczeklik A. Enhanced expression of the leukotriene C(4) synthase due to overactive transcription of an allelic variant associated with aspirin-intolerant asthma. Am J Respir Cell Mol Biol. 2000;23(3):290-6.

80. Sampson AP, Cowburn AS, Sladek K, Adamek L, Nizankowska E, Szczeklik A, et al. Profound overexpression of leukotriene C4 synthase in bronchial biopsies from aspirin-intolerant asthmatic patients. Int Arch Allergy Immunol. 1997;113(13):355-7.

81. Cowburn AS, Sladek K, Soja J, Adamek L, Nizankowska E, Szczeklik A, et al. Overexpression of leukotriene C4 synthase in bronchial biopsies from patients with aspirin-intolerant asthma. J Clin Invest. 1998;101(4):834-46.

82. Van Sambeek R, Stevenson DD, Baldasaro M, Lam BK, Zhao J, Yoshida $S$, et al. 5' flanking region polymorphism of the gene encoding leukotriene C4 synthase does not correlate with the aspirin-intolerant asthma phenotype in the United States. J Allergy Clinical Immunol. 2000;106(1 Pt 1):72-6.

83. Kawagishi $Y$, Mita H, Taniguchi M, Maruyama M, Oosaki $R$, Higashi $N$, et al. Leukotriene C4 synthase promoter polymorphism in Japanese patients with aspirin-induced asthma. J Allergy Clinical Immunol. 2002;109(6):936-42.

84. Choi JH, Park HS, Oh HB, Lee JH, Suh YJ, Park CS, et al. Leukotriene-related gene polymorphisms in ASA-intolerant asthma: an association with a haplotype of 5-lipoxygenase. Hum Genet. 2004;114(4):337-44.

85. Isidoro-Garcia M, Davila I, Moreno E, Lorente F, GonzalezSarmiento R. Analysis of the leukotriene C4 synthase A-444C promoter polymorphism in a Spanish population. J Allergy Clinical Immunol. 2005;115(1):206-7.

86. Mastalerz L, Setkowicz M, Sanak M, SzczeklikA. Hypersensitivity to aspirin: common eicosanoid alterations in urticaria and asthma. J Allergy Clinical Immunol. 2004;113(4):771-5.

87. Torres-Galvan MJ, Ortega N, Sanchez-Garcia F, Blanco C, Carrillo T, Quiralte J. LTC4-synthase A-444C polymorphism: lack of association with NSAID-induced isolated periorbital angioedema in a Spanish population. Ann Allergy Asthma Immunol. 2001;87(6):506-10.

88. Cornejo-Garcia JA, Jagemann LR, Blanca-Lopez N, Dona I, Flores C, Gueant-Rodriguez RM, et al. Genetic variants of the arachidonic acid pathway in non-steroidal anti-inflammatory drug-induced acute urticaria. Clin Exp Allergy. 2012;42(12):1772-81

89. Ayuso P, Plaza-Seron Mdel C, Blanca-Lopez N, Dona I, Campo $P$, Canto G, et al. Genetic variants in arachidonic acid pathway genes associated with NSAID-exacerbated respiratory disease. Pharmacogenomics. 2015;16(8):825-39.

90. Agundez JA, Blanca M, Cornejo-Garcia JA, Garcia-Martin E. Pharmacogenomics of cyclooxygenases. Pharmacogenomics. 2015;16(5):501-22.

91. Vidal C, Porras-Hurtado L, Cruz R, Quiralte J, Cardona V, Colas $C$, et al. Association of thromboxane $A 1$ synthase (TBXAS1) gene polymorphism with acute urticaria induced by nonsteroidal anti-inflammatory drugs. J Allergy Clin Immunol. 2013:132(4):989-91.

92. Lee HY, Kim SH, Ye YM, Choi GS, Park HS. Lack of association of ALOX12 and ALOX15 polymorphisms with aspirinexacerbated respiratory disease in Korean patients. Ann Allergy Asthma Immunol. 2009;103(1):84-6.

93. Oh SH, Kim YH, Park SM, Cho SH, Park JS, Jang AS, et al Association analysis of thromboxane $A$ synthase 1 gene polymorphisms with aspirin intolerance in asthmatic patients. Pharmacogenomics. 2011;12(3):351-63.

94. Kim SH, Kim YK, Park HW, Jee YK, Kim SH, Bahn JW, et al. Association between polymorphisms in prostanoid receptor genes and aspirin-intolerant asthma. Pharmacogenet Genomics. 2007;17(4):295-304.

95. Park BL, Park SM, Park JS, Uh ST, Choi JS, Kim YH, et al Association of PTGER gene family polymorphisms with aspirin intolerant asthma in Korean asthmatics. BMB Rep. 2010;43(6):445-9. 
96. Palikhe NS, Sin HJ, Kim SH, Sin HJ, Hwang EK, Ye YM, et al. Genetic variability of prostaglandin E2 receptor subtype EP4 gene in aspirin-intolerant chronic urticaria. J Human Genet. 2012;57(8):494-9.

97. Oguma T, Palmer LJ, Birben E, Sonna LA, Asano K, Lilly CM. Role of prostanoid DP receptor variants in susceptibility to asthma. N Engl J Med. 2004;351(17):1752-63.

98. Plaza-Seron Mdel C, Ayuso P, Perez-Sanchez N, Dona I, BlancaLopez N, Flores C, et al. Copy number variation in ALOX5 and PTGER1 is associated with NSAIDs-induced urticaria and/or angioedema. Pharmacogenet Genomics. 2016;26(6):280-7.

99. Kim SH, Oh JM, Kim YS, Palmer LJ, Suh CH, Nahm DH, et al. Cysteinyl leukotriene receptor 1 promoter polymorphism is associated with aspirin-intolerant asthma in males. Clin Exp Allergy. 2006;36(4):433-9.

100. Bizzintino JA, Khoo SK, Zhang G, Martin AC, Rueter K, Geelhoed GC, et al. Leukotriene pathway polymorphisms are associated with altered cysteinyl leukotriene production in children with acute asthma. Prostaglandins Leukot Essent Fatty Acids. 2009;81(1):9-15.

101. Arriba-Mendez S, Sanz C, Isidoro-Garcia M, Pascual M, Avila C, Davila I, et al. Analysis of 927T > C CYSLTR1 and -444A $>$ C LTC4S polymorphisms in children with asthma. Allergol Immunopathol (Madr). 2008;36(5):259-63.

102. Hong X, Zhou H, Tsai HJ, Wang X, Liu X, Wang B, et al. Cysteinyl leukotriene receptor 1 gene variation and risk of asthma. Eur Respir J. 2009;33(1):42-8.

103. Arriba-Mendez S, Sanz C, Isidoro-Garcia M, Davild I, Laffond E, Horeno $\mathrm{E}$, et al. 927T>C polymorphism of the cysteinyl-leukotriene type-1 receptor (CYSLTR1) gene in children with asthma and atopic dermatitis. Pediatr Allergy Immunol. 2006;17(5):323-8.

104. Park JS, Chang HS, Park CS, Lee JH, Lee YM, Choi JH, et al. Association analysis of cysteinyl-leukotriene receptor 2 (CYSLTR2) polymorphisms with aspirin intolerance in asthmatics. Pharmacogenet Genomics. 2005;15(7):483-92.

105. Palikhe NS, Kim SH, Lee HY, Kim JH, Ye YM, Park HS. Association of thromboxane $A 2$ receptor (TBXA2R) gene polymorphism in patients with aspirin-intolerant acute urticaria. Clin Exp Allergy. 2011;41(2):179-85.

106. Kohyama K, Hashimoto M, Abe S, Kodaira K, Yukawa T, Hozawa $S$, et al. Thromboxane A2 receptor $+795 \mathrm{~T}>\mathrm{C}$ and chemoattractant receptor-homologous molecule expressed on Th2 cells -466T>C gene polymorphisms in patients with aspirin-exacerbated respiratory disease. Mol Med Rep. 2012;5(2):477-82.

107. Plaza-Seron Mdel C, Blanca-Lopez N, Perez-Sanchez N, Dona I, Acosta-Herrera M, Pino-Yanes $M$, et al. Genetic Variants of Thymic Stromal Lymphopoietin in Nonsteroidal AntiInflammatory Drug-Induced Urticaria/Angioedema. Int Arch Allergy Immunol. 2016;169(4):249-55.

108. Kim SH, Kang YM, Kim SH, Cho BY, Ye YM, Hur GY, et al. Histamine $\mathrm{N}$-methyltransferase $939 \mathrm{~A}>\mathrm{G}$ polymorphism affects mRNA stability in patients with acetylsalicylic acidintolerant chronic urticaria. Allergy. 2009;64(2):213-21.

109. Garcia-Martin E, Ayuso P, Martinez C, Blanca M, Agundez JA. Histamine pharmacogenomics. Pharmacogenomics. 2009; 10(5):867-83.

110. Ayuso P, Blanca M, Cornejo-Garcia JA, Torres MJ, Dona I, Salas $M$, et al. Variability in histamine receptor genes HRH1,
$\mathrm{HRH} 2$ and HRH4 in patients with hypersensitivity to NSAIDs. Pharmacogenomics. 2013;14(15):1871-8.

111. Agundez JA, Ayuso P, Cornejo-Garcia JA, Blanca M, Torres MJ, Dona I, et al. The diamine oxidase gene is associated with hypersensitivity response to non-steroidal anti-inflammatory drugs. PloS One. 2012;7(11):e47571.

112. Ferreira Vasconcelos LM, Rodrigues RO, Albuquerque $A A$, Barroso GD, Sasahara GL, Severo Ferreira JF, et al. Polymorphism of IL10, IL4, CTLA4, and DAO Genes in Cross-Reactive Nonsteroidal Anti-inflammatory Drug Hypersensitivity. J Clin Pharmacol. 2017 Jul 27. doi: 10.1002/jcph.986. [Epub ahead of print]

113. Ayuso P, Plaza-Seron Mdel C, Dona I, Blanca-Lopez N, Campo $\mathrm{P}$, Cornejo-Garcia JA, et al. Association study of genetic variants in PLA2G4A, PLCG1, LAT, SYK, and TNFRS11A genes in NSAIDs-induced urticaria and/or angioedema patients. Pharmacogenet Genomics. 2015;25(12):618-21.

114. Kim LH, Chang H, Namgoong S, Kim JO, Cheong HS, Lee SG, et al. Genetic variants of the gasdermin B gene associated with the development of aspirin-exacerbated respiratory diseases. Allergy Asthma Proc 2017;38(1):4-12.

115. Agundez JA, Martinez C, Perez-Sala D, Carballo M, Torres MJ, Garcia-Martin E. Pharmacogenomics in aspirin intolerance. Curr Drug Metab. 2009;10(9):998-1008.

116. Garcia-Martin E, Esguevillas G, Blanca-Lopez N, GarciaMenaya J, Blanca M, Amo G, et al. Genetic determinants of metamizole metabolism modify the risk of developing anaphylaxis. Pharmacogenet Genomics. 2015;25(9):462-4.

117. Kim SH, Nam EJ, Kim YK, Ye YM, Park HS. Functional variability of the adenosine $A 3$ receptor (ADORA3) gene polymorphism in aspirin-induced urticaria. Br J Dermatol. 2010;163(5):977-85.

118. Kim BS, Park SM, Uhm TG, Kang JH, Park JS, Jang AS, et al. Effect of single nucleotide polymorphisms within the interleukin-4 promoter on aspirin intolerance in asthmatics and interleukin-4 promoter activity. Pharmacogenet Genomics. 2010;20(12):748-58.

119. Benito Pescador D, Isidoro-Garcia M, Garcia-Solaesa V, Pascual de Pedro M, Sanz C, Hernandez-Hernandez L, et al. Genetic association study in nasal polyposis. J Investig Allergol Clin Immunol. 2012;22(5):331-40.

120. Dekker JW, Nizankowska E, Schmitz-Schumann M, Pile K, Bochenek G, Dyczek A, et al. Aspirin-induced asthma and HLA-DRB1 and HLA-DPB1 genotypes. Clin Exp Allergy. 1997;27(5):574-7.

121. Choi JH, Lee KW, Oh HB, Lee KJ, Suh YJ, Park CS, et al. HLA association in aspirin-intolerant asthma: $\mathrm{DPB} 1{ }^{*} 0301$ as a strong marker in a Korean population. J Allergy Clin Immunol. 2004;113(3):562-4.

122. Kim SH, Choi JH, Lee KW, Kim SH, Shin ES, Oh HB, et al. The human leucocyte antigen-DRB1*1302-DQB1*0609DPB 1*0201 haplotype may be a strong genetic marker for aspirin-induced urticaria. Clin Exp Allergy. 2005;35(3):339-44.

123. Kim JH, Park BL, Cheong HS, Bae JS, Park JS, Jang AS, et al. Genome-wide and follow-up studies identify CEP68 gene variants associated with risk of aspirin-intolerant asthma. PloS One. 2010;5(11):e13818.

124. Graser S, Stierhof YD, Nigg EA. Cep68 and Cep215 (Cdk5rap2) are required for centrosome cohesion. J Cell Sci. 2007;120(Pt 24):4321-31. 
125. Chen Y, Low TY, Choong LY, Ray RS, Tan YL, Toy W, et al. Phosphoproteomics identified Endofin, DCBLD2, and KIAA0582 as novel tyrosine phosphorylation targets of EGF signaling and Iressa in human cancer cells. Proteomics. 2007:7(14):2384-97.

126. Cornejo-Garcia JA, Flores C, Plaza-Seron MC, Acosta-Herrera M, Blanca-Lopez N, Dona I, et al. Variants of CEP68 gene are associated with acute urticaria/angioedema induced by multiple non-steroidal anti-inflammatory drugs. Plos One. 2014;9(3):e90966.

127. Park BL, Kim TH, Kim JH, Bae JS, Pasaje CF, Cheong HS, et al. Genome-wide association study of aspirin-exacerbated respiratory disease in a Korean population. Hum Genet. 2013;132(3):313-21.

128. Kim SH, Cho BY, Choi H, Shin ES, Ye YM, Lee JE, et al. The SNP rs3128965 of HLA-DPB1 as a genetic marker of the AERD phenotype. PloS One. 2014;9(12):e111220.
129. Cornejo-Garcia JA, Liou LB, Blanca-Lopez N, Dona I, Chen $\mathrm{CH}_{\text {, }}$ Chou YC, et al. Genome-wide association study in NSAIDinduced acute urticaria/angioedema in Spanish and Han Chinese populations. Pharmacogenomics. 2013;14(15):185769.

\section{- José A Cornejo-García}

Research Laboratory

IBIMA, Regional University Hospital of Malaga

Plaza del Hospital Civil s/n, Hospital Civil, Pabellón 6 , $1^{\mathrm{a}}$ planta

29009 Málaga, Spain

E-mail: josea.cornejo@ibima.eu; josea.cornejo@gmail.com 